\title{
Notas sobre Formação de Professores e Ensino de Filosofia no Brasil
}

\author{
Notes on Teacher Education \\ and Philosophy Teaching in Brazil
}

\section{Resumo}

Este artigo analisa transformações em políticas públicas de educação ocorridas no Brasil nos últimos anos, com ênfase em suas consequências para o ensino de filosofia e formação de seus professores para atuação no Ensino Básico. A preocupação com essas consequências deslancha uma discussão ampla - que vai além da luta por espaço para a filosofia na grade do Ensino Médio. Trata-se de fazer o registro das múltiplas variáveis em jogo, ligando a defesa do ensino de filosofia com o esforço geral pela superação dos atuais passivos educacionais brasileiros.

Palavras-chave: Formação de professores; ensino de filosofia; BNCC; reforma do ensino médio; políticas públicas de educação.

\section{Abstract}

This article analyzes some transformations in the public policies of education occurred in Brazil in the last years, with emphasis on its consequences for the teaching of philosophy and the training of its basic education teachers. The concerning with these consequences launches a broad discussion - that goes beyond the struggle for space for philosophy in the high school schedules. The main purpose is to call attention to the multiple variables at play, binding the defense of philosophy teaching with the general effort to overcome brasilian current educational liabilities.

Keywords: Teacher training; philosophy teaching; BNCC; high school reform; public education policies.

\footnotetext{
* Departamento de Filosofia da PUC-Rio e colaborador do Mestrado Profissionalizante em Filosofia e Ensino do CEFET-RJ. E-mail: lyranetto@gmail.com.
}

Recebido em: 18/03/2019 Aceito em: 30/09/2019. 


\section{Uma difícil e necessária reflexão}

\section{I.1 O cenário recente}

É particularmente difícil - e por isso mesmo necessário - escrever sobre formação de professores e ensino de filosofia no presente momento da História do Brasil. Os anos recentes trouxeram mudanças importantes na legislação que mais amplamente cerca o tema, reflexo de disputas multifacetadas e não inteiramente evidentes em torno da definição de um projeto político-pedagógico para o país.

As mudanças incidiram mais incisivamente sobre o Ensino Médio, segmento para o qual, desde 2008, ${ }^{1}$ vinham sendo formados os professores de filosofia nas licenciaturas brasileiras. O roteiro é complexo e o cenário confuso. Misturam-se reformas legais - consumadas e não consumadas - com polêmicas ligadas ao crescimento do conservadorismo no país, de todo intensificadas com a campanha eleitoral presidencial de 2018 e a posse do novo governo. No horizonte, apenas uma certeza, anunciada e amplificada com respaldos e intenções diversas: a de que nosso modelo de Educação Básica, mais especialmente ainda o Ensino Médio, tem muitos problemas.

\section{I.2 As diatribes conservadoras}

A mais visível das mencionadas polêmicas está ligada ao movimento Escola sem Partido, que lança forte suspeita sobre as atuais práticas docentes e propõe a criminalização do que entende como atitudes doutrinárias em sala de aula. ${ }^{2}$ A ideia de que existe uma doutrinação escolar de viés ideológico esquerdista é, por sua vez, bastante difusa e abrangente, confundindo-se ora com questões de gênero e educação sexual, ora com práticas mais gerais de cunho crítico ou problematizador, por exemplo ligadas à colocação em questão dos costumes e opiniões vigentes, de todo essenciais a disciplinas como a

1 Data de 2 de junho de 2008 a Lei 11684, hoje revogada, que definia a obrigatoriedade do ensino de Filosofia e Sociologia no nível médio. Ver Governo Federal, 2008. A revogação foi operada pela Lei 13415/2017, a chamada lei da reforma do Ensino Médio. Ver Governo Federal, 2017.

2 Foram vários os projetos de lei ligados ao movimento. A versão com tramitação mais prolongada, o PL 7180, foi arquivado em 31/01/2019 (Câmara dos Deputados 2014). Não obstante o arquivamento, há uma nova versão do projeto em tramitação. Ver Câmara dos Deputados, PL246/2019. Ver ainda os sites do movimento em http://www.escolasempartido.org/ e http://www. programaescolasempartido.org/ 
História, a Sociologia ou a Filosofia. Não passe despercebido quão incisivos e diversificados são esses pleitos, a ponto de contestarem legados pedagógicos como o de Paulo Freire, pensador mundialmente citado e respeitado, inclusive em países capitalistas como os EUA e a Inglaterra. ${ }^{3}$

Talvez o mais grave entre os muitos problemas trazidos por essa insólita crônica - decerto não apenas para a Filosofia - seja a perda da atenção às nossas necessidades formativas mais básicas, de enfrentamento historicamente bastante difícil. À medida que a alegada "doutrinação ideológica" é responsabilizada pelo fracasso escolar brasileiro (mais habitualmente medido pelos padrões internacionais de avaliação), ${ }^{4}$ perde-se a discussão sobre o perverso e intrincado conjunto de carências que vai das inadequadas condições de acolhimento e trabalho na maioria das escolas públicas brasileiras até os passivos de formação, inicial e continuada, de professores para o Ensino Básico.

\section{I.3 As reformas governamentais recentes}

Fato é que parte desse conjunto de carências recebeu atenções governamentais em meio a um verdadeiro turbilhão político, ${ }^{5}$ com consequências diretas para o ensino e a formação de professores de filosofia. Essas atenções retroagem pelo menos ao Plano Nacional de Educação (PNE), de 2014, ${ }^{6}$ e à Resolução n²/2015 do Conselho Nacional de Educação $(\mathrm{CNE})^{7}$ - que dispõe sobre a reforma dos cursos de licenciatura -, e se sucedem até o final de 2018, termo final de análise deste escrito.

3 Ver Green, 2016, pesquisa baseada no Google Scholar em que a Pedagogia do Oprimido aparece como terceiro livro mais citados nas Ciências Sociais (referência que devo a Walter Kohan). Vale ainda consultar Veiga, 2019, reportagem da BBC que dá conta da publicidade da querela. A contestação foca justamente A Pedagogia do Oprimido, nomeadamente referências teóricas e políticas explícitas no livro, conquanto totalmente desatenta à veemente crítica feita pelo autor, na mesma obra, a toda doutrinação, de direita ou esquerda. A polêmica vai da pura cacofonia político-midiática a críticas feitas por filósofos sérios como Rocha, R.: Quando Ninguém Educa-questionando Paulo Freire, 2017.

4 Os resultados estão disponíveis no site do INEP: http://inep.gov.br/web/guest/pisa-no-brasil

5 O turbilhão tem seu primeiro vértice no impedimento da presidenta Dilma Rousseff e culmina na eleição do governo Bolsonaro.

6 Governo Federal, Lei 13005/2014.

7 Ver CNE 2015. Ver também CNE 2017, Parecer n¹0, de 10/5/2017, que altera o Art. 22 da Resolução em epígrafe e estende por mais um o prazo para implantação da reforma, e CNE 2018, Parecer $n^{\circ} 3$, de 3/10/2018, que o prorroga até julho de 2019. 
Assim, tanto quanto manter à vista os perigos da demonização ideológica das docências críticas, que afeta diretamente o ensino de filosofia, são problematizadas ao longo deste trabalho igualmente as reformas em curso, discutindo seus implícitos mesmo quando pretendam se justificar, política e/ou pedagogicamente, como alternativas melhores às diatribes reacionárias.

São, em suma, muitas e entrelaçadas as questões presentes no atual projeto de reformas, especialmente no que concerne a um efetivo enfrentamento das nossas lacunas educacionais em busca de uma "formação integral", da qual se fala com ênfase no corpo dos documentos em circulação. Para além de escolhas teórico-metodológicas e, claro, da observação de trâmites legais, a efetividade desse enfrentamento depende de legitimação democrática, de consenso mínimo e real pactuação entre as várias partes envolvidas no esforço, enfim, de atenção ao contexto histórico-social brasileiro. Caríssima a este trabalho é a ideia de que a esse pacto precisam aderir professores e formadores de professores, sendo, por isso, antes de tudo, absolutamente necessário identificar e reconhecer as verdadeiras e profundas razões das suas atuais carências, impotências e desprestígio.

Mais pontualmente falando, a Reforma do Ensino Médio promovida pela célere Lei 13451/2017,, 8 junto com a Base Nacional Comum Curricular ${ }^{9}$ que se lhe seguiu, de íntegra consumada somente ao final de 2018, precisam ser examinadas em suas consequências para o ensino de filosofia, para a formação e para a atuação dos professores de filosofia no nível médio.

\section{I.4 Os propósitos e o escopo do trabalho}

Feito este esboço do cenário no qual se insere o artigo, enfim, marcada a amplitude, o entrelaçamento e a possível volatilidade de algumas de suas principais referências, cabe expor as linhas gerais da contribuição a oferecer.

Tendo em conta a dificuldade de trabalhar de forma mais sistemática, o conjunto destas reflexões não aspira nenhum caráter conclusivo ou propositivo. Como seja, múltiplos foram os recursos mobilizados: 1) evocação de experiências pessoais de formação de professores de filosofia acumuladas ao longo dos anos; 2) memória de trabalho nas primeiras versões da Base Nacional Comum Curricular; 3) reflexão sobe a relação entre ensino e pesquisa

\footnotetext{
8 Ver nota 2 supra.

9 MEC 2018.
} 
na universidade brasileira; 4) análise de leis e seus possíveis efeitos de curto, médio e longo prazo para a formação de professores e o ensino de filosofia; 5) identificação dos implícitos em jogo nas transformações legais e polêmicas recentes, especialmente no que concerne a uma "formação integral".

Cláusula pétrea é que as questões relativas ao ensino e à formação de professores de filosofia não podem ser tratadas de forma avulsa e descontextualizada, precisando inserir-se de forma orgânica num projeto de educação integral. Norteia este esforço, em outras palavras, a percepção de que a discussão transcende em muito o cuidado com o mercado de trabalho dos professores de filosofia, estando em jogo a chance de as novas gerações serem capazes de algo mais que apenas dançar conforme uma música de ritmo para lá de incerto. Fazendo paráfrase de Hannah Arendt em "A Crise na Educação", ${ }^{10}$ trata-se de convidar e preparar as novas gerações para, junto conosco, enfrentarem o desafio da renovação de um mundo no qual possamos, todos e todas, dignamente viver.

\section{Mapeando as dificuldades}

\section{II.1 A depreciação da docência e dos formadores de professores}

O primeiro dos estorvos à formação docente - não sendo exceção a Filosofia - diz respeito à baixa estima que tem a sociedade brasileira contemporânea pelos professores em geral, especialmente pelos colegas da Educação Básica. Pouco prestígio social chegará a ter um professor de filosofia do Ensino Médio, mesmo que desenvolva trabalho de altíssima qualidade. É emblemática a pergunta feita em rodas sociais: - Mas você só dá aulas? ${ }^{11}$ Não sendo suficientemente convincente esse "senso comum", a pesquisa recente da Varkey Foundation, ligada à Universidade de Sussex, é implacável: coloca o Brasil na última colocação entre 35 países, num ranking de respeito pelos professores intitulado Global Status Index. ${ }^{12}$

10 Cf. Arendt 1997, p.247.

11 É especialmente difícil conceber famílias de classes abastadas que genuinamente desejem que seus descendentes lecionem na Educação Básica. Marcelo Guimarães (UNIRIO), com quem dialoguei em vários momentos da elaboração deste texto, chama atenção em sentido oposto para uma espécie de desestímulo - entre famílias menos favorecidas - relacionado à crença de que o investimento em formação docente "não é para seus filhos". Eles não disporão, em meio às muitas carências, do tempo necessário a essa formação.

12 Dolton, P.; Mercenaro, O.; De Vries, R.; \& She, P.: Global Teacher Status Index 2018. 
Essa depreciação e sua história dariam ensejo a uma enorme gama de considerações sobre nossas hierarquias trabalhistas, sociais e culturais. Mas, mesmo que não se possa aqui chegar até suas causas profundas, é possível afirmar que ela é, por si só, capaz de afastar do magistério pessoas a princípio a ele vocacionadas. ${ }^{13}$

Especialmente significativo é que essas hierarquias se refletem na própria academia, mesmo quando são no seu seio postas em questão. A ideia de excelência ainda fortemente dominante nas universidades repousa sobre parâmetros de produtividade que privilegiam abertamente a pesquisa em relação à docência. Não há dúvida de que a pesquisa é imprescindível ao desenvolvimento de qualquer campo de saber, mas é outra história que a consolidação dessa importância se faça divorciada da necessidade de reconhecimento - mesmo da simples existência - de um saber docente de valor intrínseco, capaz, ademais, se trabalhado na sua dimensão mais ampla, de fomentar diálogo mais aberto da academia com a sociedade ${ }^{14}$

Diz-se responder mais diretamente por essa assimetria um modelo de ciências cujos resultados são mais facilmente mensuráveis; mas essa explicação está longe de dar conta do fenômeno..$^{15}$ Os expoentes desse modelo são, em todo caso, os pesquisadores. Seu habitat é o laboratório, o grupo de pesquisa, o fórum de discussões em nível de pós-graduação. Talvez não faça tanta falta nesses ambientes a posse de um bom repertório docente. Os pósgraduandos já fizeram suas escolhas e lhes é suficiente serem orientados por investigadores mais experientes, no caso da Filosofia, scholars que lhes ajudem

13 Têm vindo a público algumas matérias jornalísticas chamando atenção para a falta de atratividade do magistério no Brasil. Ver, por exemplo, Fraga, E.:. "Nenhum jovem quer virar professor no Brasil, mostra exame da OCDE", reportagem da Folha de São Paulo, 2016; Cruz, M.: "Desinteresse cresce e faltam 170 mil professores na educação básica do país", reportagem para Em.com.br, 2015; e Gonzattto, M.: "Por que apenas 2\% dos estudantes querem seguir a carreira de professor?", reportagem da RBS, 2016.

14 Participei da organização, em maio de 2014, de um evento na PUC-Rio chamado "Para quem fala a filosofia?". Vários públicos foram contemplados: alunos de ensino médio, graduandos de filosofia, graduandos de outros cursos, pares filosóficos, colegas pesquisadores e professores de outras áreas, o variado público interessado em cursos de especialização e extensão, além da mídia. Não é difícil reconhecer que cada uma dessas interlocuções depende de investimento retórico específico.

15 Há quem pontue que o verdadeiro primado é o da pesquisa aplicada, modelada pela indústria, em última instância, por um mercado ávido por inovações. Esse quiasma de influências está, de todo modo, longe de ser bem visível, demandando discussões interdisciplinares aprofundadas. O documento Base Nacional Comum de Professores da Educação Básica, op. cit., escolhe retroagir ao período do Império para dar conta dessa depreciação. Ver MEC, 2018, I.1, p.10 et seq. 
na compreensão de textos e no desenvolvimento de ideias julgadas relevantes. Tudo isso é muito natural quando o resultado do trabalho é a tese, o artigo, a conferência para pares.

Essa desnecessidade de investimento na docência não pode se ratificar, entretanto, quando outros públicos entram em cena. Trata-se de uma questão de saúde quando se lida, por exemplo, com as juventudes que caracterizam o Ensino Médio regular. Os licenciandos precisam ser efetivamente preparados para a lida com seu futuro alunado. Dos professores que os formam, espera-se que conheçam os desafios envolvidos nessa lida, sendo que a conquista dessa sintonia dá enorme trabalho a quem queira dela seriamente ocupar-se, trabalho que deve ser feito, pela concepção mesma de produtividade em vigor, sem a devida "remuneração acadêmica".

Verdade é que mesmo considerando algumas modestas revisões desse paradigma, o cenário é ainda insólito para os estudantes que venceram os desestímulos sociais iniciais e matricularam-se nas licenciaturas visando a lecionar no Ensino Médio. Esses estudantes são via de regra menos importantes que os colegas que aspiram mais decididamente ao mestrado e ao doutorado, ${ }^{16}$ esses sim as verdadeiras promessas acadêmicas. Pari passu, paira sobre os professores que a eles mais de perto se dedicam, com exceções que apenas confirmam a regra, a suspeita de não serem realmente pesquisadores de primeira linha. Pode-se, inclusive, fazer paralelo com práticas hoje comuns em campos científicos "duros", onde se discute e avalia a figura do divulgador que, para disseminar o saber da sua área, precisa reservar tempo para investir na possibilidade de comunicação com públicos diversificados. ${ }^{17}$

Os mencionados parâmetros de produtividade, enfim, só lenta e recentemente vêm se modificando, obrigando os formadores de professores seja a desistirem de pesquisas academicamente mais importantes - de todo necessárias ao progresso na carreira -, seja a impossivelmente dividirem-se para atender aos standards dos programas de pós-graduação, bem podendo ser que desse imbróglio não resultem nem bons artigos nem a devida atenção aos estudantes em formação.

16 É quase desnecessário acrescentar que há, sem dúvida, alunos excelentes nos cursos de licenciatura e que há instituições que os valorizam. A aludida depreciação tem a ver com os padrões gerais de excelência em discussão.

17 Ver p. ex.: Kellner, A.: "Divulgação científica: para quem e por quem?", 2013 e Ghilardi, A.: "O preconceito acadêmico contra os divulgadores", 2016. 


\section{II.2 Sinalizações oficiais quanto à importância da formação docente}

Examinemos o Currículo Lattes, instrumento maior de registro e medição das competências acadêmicas no Brasil. É significativo o fato dele não contar com campo específico para as produções ligadas à formação de professores, fique claro, em moldes mais específicos que a introdução, em 2012, da aba de "Educação e Popularização de C\&T" ${ }^{18}$ Fora isso, o que se pode hoje lançar no Lattes é o "desenvolvimento de material didático ou instrucional" e as supervisões de estágio. Não se sabe, por exemplo, onde registrar a participação no PIBID, Programa Institucional de Iniciação à Docência, a ser discutido mais adiante. ${ }^{19}$

A falta de incentivo acadêmico ao trabalho de formação docente pode ser também visualizada no último Relatório de Avaliação Quadrienal CAPES da área de Filosofia, que cobriu os anos de 2013 a 2016. ${ }^{20}$ Ainda que o texto geral do documento da área para o quadriênio se mostre sensível às demandas docentes e à responsabilidade da pós-graduação para com os outros segmentos de ensino, o quadro de itens pelos quais efetivamente se norteou a avaliação é eloquente em sentido contrário. Foram cinco os itens avaliados e seus respectivos pesos: 1. Proposta do programa (eliminatória); 2. Corpo docente (20\%); 3. Corpo discente, teses e dissertações (35\%); 4. Produção intelectual (35\%); e 5. Inserção social (10\%).

Não é difícil antever, apenas os itens dois e cinco contemplam atenção à docência, bastante modesta mesmo nesses âmbitos. Tudo pesado, temos algo em torno de 4,5\% do total da última avaliação quadrienal formalmente dedicado ao aprimoramento e à formação docente.

Dado o escopo deste artigo, não é possível aqui restituir o cálculo que leva a essa estimativa. Mas, é suficiente um exame geral, feito pela perspectiva aqui indicada, para dar testemunho do baixo incentivo oficial dado aos programas de pós-graduação para preocuparem-se com aprimoramento e formação docente em termos amplos.

Pode-se decerto indagar se o referido Relatório Quadrienal não é especificamente um instrumento de avaliação de pós-graduações, portanto comprometido essencialmente com a pesquisa, sendo, todavia, exatamente disso que aqui se trata. Não deve passar despercebido que grande parte dos professores

18 C\&T = Ciência e Tecnologia. Ver Governo Federal, 2012/2017.

19 Seria ainda o caso de discutir a existência da Plataforma Freire - tanto suas relações com o Lattes, quanto as razões do seu relativo desconhecimento. Ver MEC 2009.

20 Ver CAPES, 2017. 
hoje atuantes nos cursos superiores de filosofia do país - por conseguinte também nas licenciaturas - é egressa do Sistema Nacional de Pós-Graduação, tendo lá obtido seus títulos de mestre ou doutor. ${ }^{21}$

Fato é que o apreço e atenção que tenham esses egressos aos saberes docentes será decisivo na constituição da futura disponibilidade de formadores de professores nas licenciaturas, qualitativa e quantitativamente. Mais é encorajar uma análise de Avaliações Quadrienais de outras áreas: tal quadro não é "privilégio" da filosofia.

\section{II.3 A baixa atratividade do magistério e o perfil dos licenciandos}

Sintonizadas com os passivos sociais e acadêmicos mencionados, as prioridades da maioria dos estados brasileiros nem de longe envolvem tornar mais atrativo o exercício público do magistério no Ensino Básico. Somam-se ao desprestígio social dos professores do segmento, as condições de trabalho precárias e as remunerações pouco atraentes, ${ }^{22}$ sobretudo se comparadas a outras profissões de igual ou menor investimento formativo e dedicação profissional. Impossível não retomar aqui, enfim, as tentativas de tipificação do assédio ideológico por professores e a consequente possibilidade de criminalização de suas práticas.

Seria o caso de pontualmente perguntar, por que alguém desejaria tornar-se professor quando: 1) não é boa a promessa de remuneração imediata; 2) são grandes os esforços necessários ao efetivo desenvolvimento profissional; 3) são precárias as condições de trabalho; 4) é baixo o prestígio social; e 5) setores mais conservadores da sociedade, de todo bastante ruidosos, entendem o livre exercício da docência como potencial elemento de corrupção moral e política dos estudantes.

As consequências dessa falta de atratividade são previsíveis e nefastas. A primeira e mais objetiva delas é a carência de professores para o Ensino Básico, o que faz, por mecanismos diversos, com que o acesso e a permanência nesses

21 Vale conferir, a esse respeito, o capítulo VIII do recente livro de Gatti, B. et all: Professores do Brasil- novos cenários de formação, Brasília, UNESCO, 2019.

22 Pesquisas recentes dão conta, por exemplo, da baixa remuneração dos professores da Educação brasileira. Ver OECD: Education at a Glance, 2018, Chapter D. Para a repercussão midiática do relatório ver Ferreira, P.: Salário mínimo pago ao professor no Brasil é um dos piores do mundo, O Globo de 11/09/2018. Para ações que hoje fogem a essa regra no Brasil, ver o caso maranhense, em Vichessi, B. e Silva, D. A.: Nova Escola, Edição 312, 03 de Maio de 2018. 
cursos precisem ser incentivados. A segunda consequência, diretamente relacionada à primeira e ao quadro geral de depreciação, é que parte significativa dos estudantes aprovados para cursar as licenciaturas se caracteriza por fortes dívidas de formação básica, aspirantes que, para tornarem-se bons professores, têm não apenas que adquirir as capacidades específicas das suas áreas de eleição, mas superar importantes deficiências de leitura e escrita, sem esquecer da persistência de interditos sociais que dificultam sua dedicação integral aos estudos.

Ilustrando este último ponto, a universidade privada em que trabalho oferece hoje, além das vagas PROUNI, ${ }^{23} 8$ bolsas anuais de $100 \%$ para alunos ingressantes que optem por cada uma das suas licenciaturas, ${ }^{24}$ quantidade que pode elevar-se mediante análise individual, pelos seus órgãos comunitários, de casos de impossibilidade de arcar com as mensalidades. A PUC-Rio oferece, enfim, um programa de ajuda ao transporte e à alimentação chamado FESP. ${ }^{25}$

Não obstante todos esses notáveis incentivos, não é possível esperar grande afluxo de candidatos nem altas taxas de conclusão das licenciaturas, tampouco uma maior fixação de egressos no magistério básico. Ainda que não tenham que pagar a universidade, muitos estudantes têm imperativamente que trabalhar; mesmo com auxílio para passagem e alimentação, perdem preciosas horas deslocando-se de casa para a universidade e vice-versa, tudo isso resultando em evasão e sendo fatores difíceis de administrar. Os que superam todos esses obstáculos, enfim, não é raro que acabem optando por concursos públicos e outros caminhos profissionais mais promissores.

\section{II.4 Estágios curriculares supervisionados}

Paralelamente ao perfil dos estudantes que optam e permanecem nas licenciaturas, constitui um nó no processo de formação docente a questão dos estágios curriculares supervisionados. Temos hoje no cenário de reformas educacionais - com deadline originalmente previsto para julho de 2017, mas adiado primeiramente para 2018 e em seguida para 2019 - a já mencionada Resolução n²/2015 do CNE. ${ }^{26}$

23 Ver MEC: Programa Universidade para Todos.

24 Ver PUC-Rio: Manual do Candidato 2019, p.46.

25 Ver PUC-Rio: Fundo Emergencial de Solidariedade da PUC-Rio.

26 Ver nota 8. 
Observe-se que entre as mudanças em pauta não está o número total de horas de "estágio supervisionado na área de formação e atuação na educação básica", que permanece em 400 horas, ${ }^{27}$ como prescrito pela legislação em vigor. ${ }^{28}$ Mesmo que se entenda que parte dessas horas possa ser cumprida na universidade - em tempo de supervisão dedicado à reflexão grupal (ou individual) sobre as experiências vividas nas escolas parceiras -, ainda assim o número de horas a permanecer no colégio é alto e de observação difícil de equacionar, sobretudo em cursos como o de Filosofia, cuja carga horária semanal varia em torno de 50 minutos para cada turma, jamais ultrapassando o dobro desse tempo. Sem colocar em dúvida a necessidade formativa dos estágios, são muitos os problemas envolvidos na sua transformação em experiências realmente significativas. ${ }^{29}$

Um agudo problema é de natureza logística. Concerne à impossibilidade de conciliação, principalmente dos estudantes que precisam trabalhar, das horas disponíveis nas grades disciplinares das escolas conveniadas com suas outras exigências de rotina, de modo a totalizarem a carga horária prescrita. Some-se ao rol destas dificuldades o problema de encontrar colégios para estagiar perto da universidade ou, alternativamente, do domicílio do estudante. Não fosse o bastante, é preciso achar instituições, públicas ou privadas, que, sem as mencionadas inviabilidades logísticas, tenham profissionais conscientes do seu papel complementar de formação de novos docentes, sobretudo professores ainda motivados com o ofício e com abertura para experimentações, o que demanda, nas condições descritas, boa dose de idealismo. Visto que muitos desses colegas trabalham em condições precárias, não é raro que a presença do estagiário represente mais um problema a administrar. Compreende-se que um professor que não consegue realizar um bom trabalho não se sinta confortável com a presença de uma "testemunha"; ou que a sobrecarga das muitas turmas sob sua responsabilidade transforme o estagiário em mais um peso a carregar, ao qual não é possível dispensar o devido cuidado e estímulo. Enfim, ainda que nada disso aconteça, e que estejamos falando de profissionais especialmente empenhados em contribuir para a formação dos futuros colegas, precisarão ambos - professor e estagiário - contar com

27 Ver CNE, 2015: Resolução n²/2015, Art. 13, § 1ª Inciso II.

28 Ver CNE, 2002. Resolução CNE/CP n², de 19 de fevereiro de 2002, em seu Art. 1ª Inciso II.

29 No horizonte estão ainda os efeitos da Lei 13415 para o ensino de filosofia no nível médio, discutidos no item III deste artigo. 
ventos efetivamente favoráveis, no mínimo, com um calendário escolar em que os espaçamentos semanais entre aulas não se tornem ainda maiores por força de greves e outras interrupções, mesmo de simples feriados. ${ }^{30}$

Alguns colégios das redes privadas abertos ao acolhimento de estagiários apresentam ainda um outro tipo de problema. Os pais dos seus alunos pagam para que eles aprendam com professores e, a não ser que essas instituições tenham programas de estágio muito bem definidos e amadurecidos, não é de se esperar que os regentes concedam maior protagonismo aos estagiários, cujos resultantes papéis passivos pejorativamente lhes rendem no Rio de Janeiro o apelido de "estagiários-samambaia". Registre-se ainda nessa esteira que nenhum incentivo legal é destinado àquelas instituições, privadas ou públicas, que assumem parcerias de estágio realmente formativas. Elas têm que fazê-lo por livre e espontânea vontade e consciência de responsabilidade, muitas vezes a contrapelo das circunstâncias.

Contornar todos esses problemas significa para os cursos de licenciatura, enfim, consolidar uma possível rede de parcerias que permita acomodar digna e produtivamente seus licenciandos, mesmo porque não se pode concentrar número excessivo de estagiários num único colégio que, porventura, ofereça as condições descritas.

Recorro mais uma vez à minha própria experiência de trabalho. Apesar do bom acervo de escolas conveniadas institucionalmente ao meu alcance, está ainda assim longe de ser fácil "alocar" adequadamente todos os estagiários de uma mesma turma. Escolhi por isso liberá-los para procurar escolas além do entorno geográfico da universidade. Essa providência, embora tenha ampliado a possibilidade de encontrar instituições que atendam às condições enumeradas, dificultou em muito o acompanhamento in loco das atividades. É, em todo caso, uma providência aplicável somente a universidades com turmas reduzidas de licenciatura ou, o que é raro, com professores auxiliares atuando na supervisão de estágios.

30 Mais uma vez lembrado por Marcelo Guimarães, acrescento o problema das práticas avaliativas, que em alguns colégios tomam tempo desproporcionalmente grande e não têm, no mais das vezes, qualquer propósito formativo. 


\section{II.5 O PIBID}

Se não é possível aqui inventariar todas as dificuldades com que se deparam os coordenadores de programas de licenciatura, não se pode deixar de evocar a experiência formativa proporcionada pelo PIBID - Programa Institucional de Bolsas de Iniciação à Docência. ${ }^{31}$

A bolsa oferecida aos professores das escolas parceiras que acolhem os "pibidianos" funciona - ainda que seu valor não seja elevado ${ }^{32}$ - como incentivo àqueles profissionais que, por força do compromisso assumido, e com a anuência das escolas, disponham-se prioritariamente a transformar a presença dos estagiários em sala num ganho geral para o ensino. Também os coordenadores dos projetos PIBID nas diversas licenciaturas recebem bolsas CAPES ${ }^{33}$ que, ainda que não mexam com a necessidade de continuarem dividindo-se para dar conta das nuances da produtividade acadêmica, contribuem para reposicionar suas atividades formativas na universidade, tanto em termos de remuneração quanto de prestígio. As ações do PIBID funcionam sobretudo de forma coletiva, possibilitando um tratamento mais programático ou projetivo das atividades na escola e dando maior visibilidade às suas ações na universidade.

Por tudo isso, soou estranho que não se avançasse em direção ao uso desse programa para rediscutir os estágios curriculares supervisionados, ou mesmo considerar a integração entre eles e o PIBID. Sequer se discutia o número de horas que um bolsista PIBID podia abater da sua carga obrigatória de estágio supervisionado, sendo que o funcionamento paralelo das duas práticas acabava por produzir comparações e tensões indesejadas no processo formativo.

Preocupou-se, em vez disso, ainda o governo em continuidade com aquele que exitosamente criou o PIBID, com a ideia de que o dinheiro público gasto no programa não estaria sendo revertido para a melhoria da qualidade do ensino público básico, livres que estavam as universidades para escolher as escolas parceiras e o fizessem considerando principalmente suas próprias conveniências. Não era outra coisa o que perseguia a mal recebida Portaria 46

31 Instituído pela Portaria normativa n. 38 do MEC, de 12 de dezembro de 2007. Ver CAPES. PIBID 2007 para conferir o primeiro edital e CAPES: PIBID, Portal para as atualizações.

32 O valor nacional até fevereiro de 2019 segue sendo de $\mathrm{R} \$ 750,00$. Era de $\mathrm{R} \$ 600,00$ na primeira edição do programa, em 2008. Dependendo do estado brasileiro, pode representar acréscimo de remuneração mais ou menos relevante.

33 O valor nacional correspondente é de $\mathrm{R} \$ 1400,00$ 
da CAPES - revogada depois de muitos protestos em 15/06/2016 ${ }^{34}$ - senão transformar o PIBID em um programa de reforço escolar, mais que de formação de professores. Parecia não passar pela cabeça daqueles gestores o conjunto de problemas aqui listados quando da descrição das dificuldades de alocação dos estagiários nos colégios em busca de boas experiências formativas.

Com a mudança de governo motivada pelo impedimento presidencial de 2016, toda essa hesitação acabou dando ensejo a descontinuidades - ou aperfeiçoamentos, como oficialmente alegado - como aquelas promovidas pelas publicações dos Editais CAPES 6 e 7/2018, ${ }^{35}$ que instituíram, respectivamente, o programa de Residência Docente e reformularam substancialmente o PIBID.

Não é o caso aqui de discutir em maior detalhe as transformações trazidas por essas novas políticas, mas de apontar algumas de suas linhas mais relevantes para a presente discussão. O PIBID passou a ser um programa para licenciandos em início de curso, cabendo ao programa de Residência Docente a absorção daqueles com mais de $60 \%$ dos créditos cursados ${ }^{36}$ Não obstante, continua sem definição clara - e tanto mais necessária na medida em que o volume de recursos destinados a esses programas não permite neles alocar a totalidade dos licenciandos de cada curso - qual a relação, por exemplo, entre a nova Residência e os antigos estágios curriculares.

\section{II.6 A Proposta para Base Nacional Comum de Formação de Professores da Educação Básica}

É preciso neste ponto evocar e analisar a elaboração pelo MEC, ainda no governo Temer e em versão preliminar, do documento intitulado Proposta para Base Nacional Comum de Formação de Professores da Educação Básica. Enviada ao Conselho Nacional de Educação em 14/12/2018, ${ }^{37}$ ou seja, a dezoito dias da posse de um novo governo e gestão do MEC, a proposta lida ao seu modo com os problemas até aqui identificados e entrelaçados.

\footnotetext{
34 A Portaria foi assinada em 11/04/2016 e revogada pela Portaria 84/2016. Ver CAPES: PIBID, Portaria 46/2016 e Portaria 84/2016.

35 Ver CAPES: Edital 6/2018 e Edital 7/2018.

36 Ver CAPES: Edital 7/2018, item 2.3.1.

37 Ver MEC: Proposta de Base Nacional Comum de Formação de Professores da Educação Básica, 2018.
} 
O documento foi elaborado no ritmo que caracterizou o MEC do governo Temer: partiram do trabalho que vinha sendo tocado mais democrática e lentamente pelo governo anterior e lhe deram celeridade às custas da tomada de decisões decerto técnicas, mas muitíssimo menos lastreadas em consulta pública. Foi o caso da introdução na LDB e na BNCC, via Lei 13415/2017, da linguagem das "competências e habilidades", típica dos Parâmetros Curriculares Nacionais (PCNs) ${ }^{38} \mathrm{O}$ Plano Nacional de Educação (PNE), por exemplo, fruto de longos dissensos até sua aprovação no legislativo em 2014, estruturava-se em termos de "direitos e objetivos de aprendizagem" e assim foram trabalhadas as duas primeiras versões da BNCC. A Proposta ora em análise trata, inclusive, de esclarecer melhor esses conceitos referindo-os à obra do sociólogo suíço Philippe Perrenaud. ${ }^{39}$ Mas, faz-se autorreferente ao abrir sua Seção III (Matriz de Competências Profissionais), com o seguinte parágrafo: "O currículo comprometido com o desenvolvimento de competências constitui hoje um paradigma dominante na educação do Brasil e de muitos outros países."

O problema é que a ideia técnica de "competência" só é introduzida na LBD por ação da Lei 13415, ou seja, pelos próprios gestores da Proposta. Sem qualquer intenção de impugnar, sem os devidos debates, a insistência no par conceitual "competências e habilidades", o fato é que ele não pode, especialmente no contexto descrito, justificar-se como "paradigmático".

Não pode, enfim, passar sem registro que um outro importante dispositivo da mesma época da Proposta, a Resolução MEC/CNE/CEB n³, de 21/11/2018, que "atualiza das Diretrizes Curriculares Nacionais para o Ensino Médio", preocupa-se em anotar:

Para os efeitos desta Resolução, com fundamento no caput do art. 35-A e no $\S 1^{\circ}$ do art. 36 da LDB, a expressão 'competências e habilidades' deve ser considerada como equivalente à expressão "direitos e objetivos de aprendizagem" presente na Lei do Plano Nacional de Educação (PNE). ${ }^{41}$

38 Cheguei a tratar mais detidamente desse resgate da linguagem das "competências e habilidades" na resposta à segunda questão de entrevista dada à ANPOF em 2018. Ver Lyra, E., 20172018. Os PCNS começaram a ser publicados em 1997, na esteira da LDB. O documento que versa sobre o Ensino Médio, em cujo texto a noção de "competência" é central, foi dado a público em 2000 e está disponível em MEC 2000.

39 MEC, op. cit., p.41.

40 Idem.

41 Ver Governo Federal, 2018. 
Fato é que o texto da Proposta para Base Nacional Comum de Formação de Professores da Educação Básica privilegia aspectos curriculares que, tendo a BNCC como termo, define as competências gerais e específicas que os professores precisarão desenvolver e, a partir das quais, serão formados e avaliados. ${ }^{42}$ É, na verdade, todo um conjunto de ações de formação, avaliação, certificação e consolidação que assim se pretende fundamentar. A Residência Pedagógica propõe-se a finalmente substituir os estágios curriculares. Institui-se um ENADE específico para as licenciaturas e também estágios probatórios de início de carreira. Impossível não registrar, ações anteriores mais ou menos exitosas em torno da formação e aperfeiçoamento docente, como o já mencionado PIBID, além de várias outras discutidas mais adiante, no eixo Ensino Superior-Ensino Básico, como o PRODOCÊNCIA, o OBEDUC e o PARFOR, simplesmente não figuram no texto da Proposta.

Trata-se de um documento ímpar. Tem como mérito diagnosticar, com ênfase e lastro internacional, a necessidade de prestar central atenção ao professor e sua formação, no que concerne a quaisquer ações de superação dos nossos passivos educacionais. ${ }^{43}$ Registra a partir de pesquisa do Centro de Estudos e Pesquisas em Educação, Cultura e Ação Comunitária (CENPEC) o fato de haver visões distintas sobre referenciais docentes no Brasil. ${ }^{44}$ Olha para experiências de vários países, sendo capaz de assinalar a existência de caminhos diferentes de enfrentamento desses passivos. (Seção I.III) Tudo isso para saltar, como se assim não fosse, para a abrangente, singular e ousada Proposta entregue ao CNE.

A perplexidade se renova ao final no documento, na Seção IV, de título "Limites e Indicações". Lê-se:

Neste capítulo destacam-se os limites da Base Nacional Comum de Formação de Professores da Educação Básica e as indicações para o seu efetivo impacto no sistema educacional brasileiro. Conforme apresentado no capítulo referente às experiências no plano internacional, para que um documento referencial se concretize na regulação das políticas públicas de formação, é necessário que ele proponha mudanças sistêmicas nas diversas acões que envolvem os professores. Por esse motivo, este capítulo reflete uma

42 Ibidem nota 42, p. 49 et seq.

43 Ibidem p.5. O texto remete ao relatório 2005 da OECD e ao chamado Relatório Mac Kinsey, de 2008 .

44 Ibidem p.17. 
preocupação na aplicabilidade da normativa para a valorização docente. O capítulo, portanto, destaca qual o limite de atuação dessa diretriz e quais as indicações para as ações que o documento demanda. ${ }^{45}$ (grifo meu)

Em se tratando de discutir "limites" para o "efetivo impacto" das propostas contidas no documento, era de se esperar atenção especial aos fatores contextuais não colocados em quadro, muitos dos quais enfatizados neste artigo. Ao mesmo tempo em que se fala de "mudanças sistêmicas nas diversas ações que envolvem os professores", o que se tem nesse capítulo final é uma listagem aberta e especulativa de ações suplementares, enfim, nem de longe um balanço dos limites da Proposta, uma genuína autocrítica ou um conjunto de considerações mais distanciadas e atentas ao entrelaçamento dos nossos atuais problemas. São deixadas de lado, é preciso insistir em se tratando de pacto a estabelecer, as razões mais amplas pelas quais são hoje tão insatisfatórios os resultados do trabalho dos professores da Educação Básica, por exemplo, fatores de remuneração, condições de trabalho, prestígio social e acadêmico.

Pode-se concordar com o texto geral do documento sobre a existência de fatores que escapam à possibilidade de ação mais imediata do MEC em sua jurisdição federal, e que por isso é preciso focar em ações mais pontuais e prescritivas. Só que nesse passo voltamos ao problema da efetividade de quaisquer conjuntos de medidas a adotar para a superação ou mitigação dos nossos passivos educacionais básicos. Levada a termo, a "valorização docente" presente na passagem citada apontaria primeirissimamente para o reconhecimento da situação precária, insólita, na qual trabalha boa parte dos nossos professores do ensino público básico. Esse reconhecimento é mandatório seja por questões ético-políticas, seja porque esses docentes não podem ser súbita e simplesmente substituídos por colegas mais novos e bem formados, tampouco reorientados sem que se sintam partícipes e concernidos - justamente concernidos - por quaisquer conjuntos de medidas sistemáticas que se venha a promulgar.

Chamo atenção, em suma, para a necessidade de pensar a superação dos nossos estorvos numa perspectiva ampla e realista, integral e integrada, aberta à discussão e à legitimação democrática. Quem quer que venha a conduzir essas muito necessárias discussões, precisará estar comprometido com a busca de unidade, de contextualização, de legitimação e efetividade do conjunto de ações a ser levado a termo. Não é difícil vislumbrar a esta altura quantas

45 Ibidem, p.57. 
são as variáveis a administrar para que um estudante de licenciatura receba uma formação docente realmente boa, formação a cargo - é preciso insistir - de professores universitários inseridos no contexto acadêmico já definido neste texto, enfim, escassos em número, motivação e disponibilidade.

\section{História recente do ensino de filosofia no Brasil}

\section{III.1 A formação dos professores para o Ensino Superior}

Falar da história recente da formação de professores de filosofia no Brasil significa quase que exclusivamente falar de preparação de profissionais para o Ensino Médio. Embora exista para os bolsistas de pós-graduação da CAPES a exigência de "estágio docência", essa não costuma ser uma experiência de efetiva formação docente. Esses estágios acabam, no mais das vezes, reproduzindo a lógica da apresentação de pesquisas acadêmicas. Dadas as prioridades evidenciadas neste artigo, seria mesmo difícil imaginar algo diferente.

Fato é que grande parte dos professores que leciona no Ensino Superior, incluídas as graduações, não teve qualquer formação docente - inicial, complementar ou continuada -, a menos que tenham antes passado por uma licenciatura. Não sendo o caso, ou bem esse professor percebe, sozinho, a necessidade de continuadamente ressignificar sua práxis docente e entrar em interlocução com aqueles que com isso se preocupam, nos departamentos de Educação ou alhures, ou passará a vida norteando-se por pressupostos que desaconselham quaisquer novos investimentos na docência.

É verdade que a própria CAPES despertou em tempos relativamente recentes para a necessidade de combater a escassez de quadros para o Ensino Básico lançando uma série de programas como o PRODOCÊNCIA (2006), ${ }^{46}$ o OBEDUC (2006), ${ }^{47}$ o já mencionado PIBID (2008) e o PARFOR (2009), ${ }^{48}$ cada um com sua tipicidade e história própria de sucessos e insucessos. Necessário insistir, nenhum desses programas recebe atenção na Proposta para Base Nacional Comum de Formação de Professores da Educação Básica.

46 Programa de Consolidação das Licenciaturas, último edital em 2013, cobrindo 24 meses. Ver CAPES: PRODOCÊNCIA.

47 Observatório da Educação, último edital em 2012, prazo máximo de execução de 48 meses. Ver CAPES: OBEDUC.

48 Plano Nacional de Formação de Professores para a Educação Básica, último edital em 2018. Ver CAPES: PARFOR. 


\section{III.2 A formação de professores de filosofia para o Ensino Médio}

No que concerne especificamente à formação de professores de filosofia para o Ensino Médio, convém discutir em mais detalhe a história do marco legal posto pela Lei 11684/2008, que incluía via LDB "a Filosofia e a Sociologia como disciplinas obrigatórias em todas as séries do ensino médio". ${ }^{49}$ A busca por essa obrigatoriedade legal vinha de mais tempo, com "resoluções" favoráveis exaradas pelo $\mathrm{CNE}^{50}$ e mesmo existência de redes escolares que, espontaneamente, entendiam como desejável a presença da Filosofia em seus projetos educacionais. Observe-se que a perseguida obrigatoriedade havia sido aprovada pelo Poder Legislativo em 2000, ${ }^{51}$ sendo, contudo, vetada pelo presidente Fernando Henrique Cardoso $^{52}$ sob a alegação de que não haveria professores disponíveis em quantidade para fazer frente à demanda gerada. ${ }^{53}$

Finalmente aprovada a obrigatoriedade em 2008, foi feito um gigantesco esforço por grupos de professores de todo o país para pensar com a devida atenção o ensino de filosofia, sobretudo adequá-lo ao novo público. Conquanto tivessem diante si os obstáculos aqui listados, tais esforços renderam notáveis dividendos. A bibliografia dedicada às questões próprias desse ensino se avolumou e pluralizou, com a inclusão da Filosofia no PNLD em 2016 e aprovação de 8 livros didáticos em 2018. ${ }^{54}$ Proliferaram listas de discussão na internet, como a Pinaxos e a Filosofia e Ensino (ex Filosudeste), ambas hoje com mais de 600 inscritos. Surgiram grupos de estudo e pesquisa sobre ensino de Filosofia, além de eventos espalhados pelo território nacional e mesmo

49 Governo Federal. Lei 9394/1996, Art. 36, Inciso IV.

50 Ver CNE: Resolução CNE/CEB n4, de 16 de agosto de 2006.

51 Registre-se o falecimento em 2019 do Padre Roque Zimermann, figura de proa na defesa legislativa da necessidade da filosofia e da sociologia na formação média. Ver ANPOF 2019, nota de pesar.

52 Ver Câmara dos Deputados: PL n 2/2000, originalmente PL n 3178/1997, aprovado no Congresso Nacional e vetado pela Presidência da República em 2001.

53 Estadão: FHC veta filosofia e sociologia no ensino médio, 2001.

54 Ver MEC: PNLD 2018. Independente do PNLD, cito entre os livros especificamente voltados para o ensino de filosofia: Ceppas, F., Oliveira, P. R. e Sardi, S. A. (Org.): Ensino de Filosofia, formação e emancipação. Campinas, SP: Editora Alínea, 2009; Cerletti, Alejandro: O ensino de filosofia como problema filosófico. Tradução de Ingrid M. Xavier. Belo Horizonte, Autêntica, 2009; Gallo, Sílvio e Kohan, W. O. (Org.): Filosofia no Ensino Médio. Petrópolis, RJ, Vozes, 2000; Kohan, W. O.: Filosofia - o paradoxo de aprender e ensinar. Tradução de Ingrid Müller Xavier. Belo Horizonte, Autêntica Editora, 2009; Porta, M. A. G.: A Filosofia a partir dos seus problemas. São Paulo, Loyola, 2002; Rocha, R. Pires: Ensino de Filosofia e Currículo. Petrópolis, RJ, Vozes, 2008. 
internacionalizações. Foi acolhido pela ANPOF (Associação Nacional de Pós-Graduação em Filosofia) o GT Filosofar e Ensinar a Filosofar ${ }^{55}$ e, em 2012, no XV Encontro da Associação, teve lugar a primeira ANPOFEM (ANPOF do Ensino Médio). Os últimos números relativos ao ensino de filosofia são impressionantes: 195 trabalhos foram apresentados no XVII Encontro Nacional realizado na UFES em novembro 2018, cerca de 10\% do total de trabalhos apresentados no evento. ${ }^{56}$

Numa espécie de coroação de esforços, foi homologado em 2015 o primeiro Mestrado Profissionalizante em Filosofia e Ensino do Brasil, no CEFET do Rio de Janeiro, ${ }^{57}$ seguido em 2017 da primeira turma do PROF-FILO, ${ }^{58}$ Mestrado Profissional em Filosofia (semipresencial), com coordenação centralizada na UFPR e núcleos distribuídos por 17 universidades públicas de todo país. Suas duas linhas de pesquisa? - 1) Filosofia e Ensino; e 2) Prática de Ensino de Filosofia.

Não obstante os problemas descritos nas primeiras partes deste artigo estarem longe de ser superados, tudo ia razoavelmente bem com a inserção da filosofia na educação de nível médio. Os resultados eram significativos. As "ocupações" de colégios em vários estados do Brasil, de que foi pródigo o ano de 2016, revelaram com certa sonoridade o apreço que muitos alunos haviam adquirido pelo ensino da filosofia. A "escola sem sentido", que essencialmente originava as ocupações, trazia à luz o pleito por mais tempos semanais de aulas de filosofia e sociologia, lugares ou momentos - como ouvi de alguns secundaristas - "onde podiam ao menos colocar em questão a falta de sentido da formação que recebiam". Era simplesmente impressionante que professores em condições precárias e com escasso tempo semanal de aulas pudessem gerar nos alunos desejo de maior contato com suas disciplinas. ${ }^{59}$

55 O grupo existe desde 2006.

56 Ver ANPOF 2018.

57 Ver CEFET: Mestrado em Filosofia e Ensino.

58 Ver UFPR: PROF-FILO.

59 Organizei, primeiro junto com colegas dos departamentos de Educação (Waleska Mendonça e Patrícia Coelho) e Ciências Sociais (Marcelo Burgos) da PUC-Rio, depois de universidades como a UENF, UERJ, UFF, UFRJ, UFRRJ e UNIRIO, de dois grandes eventos visando dar voz aos alunos ocupantes das várias escolas do Rio de Janeiro: o OCUPA-PUC, realizado na Gávea, auditório do RDC, em 18/5/2017, e o OCUPA-EM, que teve lugar no auditório histórico da Associação Brasileira de Imprensa (ABI), em 6/6/2017. 


\section{III.3 A Lei 13415, a BNCC do Ensino Médio e suas consequências para o ensino de filosofia e a formação dos seus professores}

Desde 2015 o MEC trabalhava na elaboração da Base Nacional Comum Curricular, exigência reafirmada pelo Plano Nacional de Educação. Participei desse esforço como assessor da área de Ciências Humanas até a conclusão da segunda versão do documento, quando houve a mudança na Presidência da República e na gestão do MEC. O texto base para o ensino de Filosofia vinha, na medida do possível, sendo discutido com as várias partes interessadas. Cheguei a publicar algumas considerações sobre essa construção e sua posterior descontinuidade. ${ }^{60}$

Ponto seminal é que logo no início do novo governo veio a MP 746, em setembro de 2016. A Medida Provisória tramitou com grande rapidez até tornar-se Lei, em fevereiro de 2017. Conhecida como "Lei da Reforma do Ensino Médio", a Lei 13415 trouxe entre suas muitas novidades a revogação da obrigatoriedade do ensino de filosofia e sociologia nos três anos da etapa, passando assim a pautar discussões, inclusive a elaboração da BNCC para o Ensino Médio.

A LDB foi objetivamente alterada para dispor que "a Base Nacional Comum Curricular referente ao ensino médio incluirá obrigatoriamente estudos e práticas de educação física, arte, Sociologia e Filosofia." ${ }^{11}$ (grifo meu)

Longamente adiada por força das mudanças descritas, a BNCC do Ensino Médio só foi aprovada pelo CNE em dezembro de 2018, véspera de nova mudança de governo, enfim, dados os dissensos internos que precederam essa aprovação, ${ }^{62}$ provavelmente em função dos riscos de deixá-la ao sabor dos ventos por vir. Como seja, o documento define "habilidades e competências" específicas somente para as áreas de Língua Portuguesa e Matemática, deixando as Ciências da Natureza e as Ciências Humanas e Sociais Aplicadas sem esse detalhamento e, claro, dando motivo a muitas especulações. Conjugada essa prescrição seletiva à introdução legal no Ensino Médio dos chamados

60 Andrade, É.; Naves de Brito, A. e Lyra, E.: "Entrevista com Edgar Lyra sobre a Base Nacional Comum Curricular (BNCC)"; e Lyra, E.: "BNCC - para professor Edgar Lyra, formação básica não deve ter o mercado de trabalho como termo". Vale registrar que a proposta para a filosofia foi - não sem proveitosos dissensos - desde o início "minimalista", visando a deixar espaço para que professores bem formados pudessem, sem sacrifício do "comum", encontrar caminhos de real troca com seus públicos.

61 Governo Federal: Lei 9394/1996, modificada pela Lei 13415/2017, Art. 35 A, \&2.

62 Ilustrativa da radicalidade desses dissensos é a carta de demissão do conselheiro César Callegari. Ver Callegari, 2018. 
"percursos formativos", seguem gestores, professores e professoras envolvidas no imenso esforço aqui relatado, até o momento, sem saber o que significam os tais "estudos e práticas" e como eles devem efetivamente materializar-se nos novos planos político-pedagógicos e currículos. ${ }^{63}$

Chamo atenção para um último ponto. O texto da Lei 13415 estabelece teto de 1800 horas para a observação das prescrições da BNCC, mas não determina nenhum piso para esse mesmo cumprimento, o que deixa ainda mais indefinida a questão da carga horária e modo de oferecimento da filosofia no Ensino Médio, consequentemente, a necessidade de professores com formação específica para esse ensino. Teme-se, entre outras coisas, que essa falta de garantia de presença mínima das Ciências Naturais, Humanas e Sociais Aplicadas reforce a ideia do "currículo reverso", ${ }^{64}$ determinado pela ênfase dada no ENEM a cada grupo de competências e habilidades.

Não é difícil perceber quanta incerteza tudo isso gera não apenas para gestores de escolas e rede, mas, indistintamente, para formadores de professores, licenciandos e professores de filosofia em atividade.

\section{IV. À guisa de conclusão: a importância formativa da filosofia}

A discussão sobre a reforma pautada pela Lei 13415 vai longe, misturando questões propriamente pedagógicas - como as que dizem respeito às ideias de formação básica em contenda no Brasil e no mundo -, com questões menos nobres e visíveis, que englobam questões de igualdade de direitos e expectativa de lucro para investimentos em educação básica.

É de importância não perder de vista que a tentativa de implementação de reformas não suficientemente discutidas ou pactuadas, sem significativa adesão das partes envolvidas, pode muito bem definir a piora do pouquíssimo que ainda publicamente temos, seja em termos de formação para o mercado de trabalho, seja na construção de uma sociedade de cidadãos, e não apenas de consumidores.

63 Registre-se a publicação em 28 de dezembro de 2018 da Portaria MEC 1432 que "estabelece os referenciais para elaboração dos itinerários formativos conforme preveem as Diretrizes Nacionais do Ensino Médio." Ainda não houve tempo para aferir a recepção dessa nova prescrição, no qual sequer consta da palavra "filosofia", em sentido lato ou estrito.

64 Devo à professora Alícia Bonamino, do Departamento de Educação da PUC-Rio, a atenção a esse fenômeno. 
Não há, a rigor, forma de defender insofismavelmente este ou aquele modelo de formação básica, mesmo a necessária presença do ensino de filosofia nessa formação. A ANPOF chegou a abrigar um vigoroso debate sobre essa necessidade por ocasião da publicação da MP $746 .{ }^{65}$ Publiquei na ocasião um pequeno texto que, por ainda me satisfazerem seus argumentos, aqui parcialmente recupero à guisa de finalização deste artigo. Chama-se "Sobre a Importância da Filosofia na Formação Básica". ${ }^{66}$

Seu pressuposto central, evocado na introdução deste artigo, é o de educar as novas gerações para que possam responsabilizar-se pelo mundo e assumir a tarefa de renová-lo. Não importa se entre "direitos e objetivos de aprendizagem" ou entre "competências e habilidades", é central a definição de um conjunto inclusivo de práticas e referências que possa, simultaneamente, receber o nome de "mundo" e encorajar a pergunta pelo seu sentido, de forma que os estudantes possam nele sentir-se inseridos e empenhados em mudá-lo para melhor.

Essa ideia deixa naturalmente espaço para múltiplas negociações, em especial aquelas que se referem ao conjunto de saberes a priorizar na construção da ideia inicial de mundo junto aos educandos, sendo disso que a BNCC trata - ou deveria tratar. De todo modo, havemos de estar falando de um mundo plural, onde haja lugar para a lida com a diferença e o dissenso, por isso mesmo com a norma, com a exceção e com a razão de ser da norma. Mesmo a defesa de um Ensino Médio formador de gente mais técnica e imediatamente preparada para o mercado de trabalho, dificilmente pode prescindir de atenção a esses cuidados.

Ainda que se deseje, em função dos indicadores de avaliações nacionais e internacionais, priorizar saberes básicos como a leitura e o cálculo, não se entende como pode, justo o Ensino Médio, ter apequenada a atenção às capacidades de questionar, de colocar em perspectiva, de julgar reflexiva e autonomamente, de estranhar, tomar distância e cobrar sentido, todas muito caras à filosofia.

Mais ainda num mundo marcado por imperativos tecnológico-desenvolvimentistas, pela modificação das próprias formas de conhecer, ensinar e aprender, enfim, por verdadeiro dilúvio informativo, torna-se difícil compreender a falta de uma atenção básica ao necessário desenvolvimento das capacidades de filtragem, digestão e lida com nossas aceleradas transformações. Não custa lembrar, estamos a um ano do advento da banda $5 \mathrm{G}$ e da

65 Ver coluna ANPOF, outubro de 2016 a fevereiro de 2017.

66 Lyra, 2016. 
viabilização da "internet das coisas", ainda, especula-se, a dez anos da ligação do nosso córtex cerebral à nuvem, enfim, a vinte e cinco anos da singularidade tecnológica. ${ }^{67}$ Chega a se bizarro nesse cenário remover a filosofia do currículo do Ensino Médio, em vez de comprometê-la como a problematização responsável desse porvir.

Pode-se, com razão, contestar que caiba exclusivamente à filosofia a responsabilidade pela formação capaz de dar dimensão e sentido aos desafios tecnológicos. Mas não é minimamente razoável desistir dela como componente curricular, sob o pretexto de preservá-la em transversalidades incertas, especialmente na carestia nossa de cada dia e na "abertura" que ora ganham as grandes áreas de Ciências Naturais e Ciências Humanas e Sociais Aplicadas.

Vale nesse último sentido registrar que a discussão sobre possíveis transdisciplinarizações - e formação de professores aptos a esse trabalho - esteve presente em projetos de lei de tramitação morosa, como aquele elaborado pelo deputado Reginaldo Lopes, ${ }^{68}$ projeto, inclusive, aqui e ali usado como justificativa para a celeridade com que foi aprovada a Lei 13415.

É evidente a complexidade da questão, e justamente por isso não se pode entender a reforma em epígrafe como corajosa, melhor lhe cabendo, no contexto político em que foi avançada, o epíteto de temerária. Foram muitas as vozes que se levantaram para apontar suas incongruências, nenhuma delas ouvida no brevíssimo interregno que foi da promulgação da MP 746 à aprovação da Lei 13415 pelo Legislativo. Não é possível, num artigo que já começa a extrapolar as dimensões canônicas, restituir o conjunto de críticas que inclui de argumentos pedagógicos a questões logísticas. ${ }^{69}$ Bem "ouvida", em todo caso, foi a advertência de que a reforma - e a tentativa de a ela adaptar a BNCC - aprofundaria o fosso já existente entre a educação oferecida para a parcela abastada da população e a educação pública, sendo emblemática, nesse coro de críticas, a carta endereçada ao CNE, em meados de 2018,

67 Ver, por exemplo, no site Futurism, braço de divulgação da Singularity University, a reportagem com Ray Kurzweil, feita por Reedy, C.: Kurzweil Claims That the Singularity Will Happen by 2045, de 5/10/2017. Kurzweil, não custa lembrar, é hoje o diretor de engenharia do Google. Registre-se, por fim, que está longe de ser consensual o seu otimismo em relação aos referidos desdobramentos.

68 Câmara dos Deputados: PL 6840/2013.

69 Cheguei a gravar uma sequência de cinco vídeos respondendo a questões postas pela ANPOF sobre esse assunto. Ver Lyra, E.: BNCC 1-5, 2018. 
pelo então demissionário conselheiro Cesar Callegari. ${ }^{70}$ Sim, pondo de lado o âmbito privado e sua eventual capacidade de beneficiar-se da flexibilidade curricular oferecida pela reforma - inclusive com novos investimentos em filosofia -, é preciso perguntar como se espera que ela possa ser posta publicamente em prática sem ferir de morte a ideia de uma "educação integral", especialmente no que essa ideia, na sua elasticidade, tenha de se relacionar com os desafios éticos e civilizacionais dos novos tempos acima postos em tela.

Concretamente falando, cerca de $42 \%$ dos municípios brasileiros têm nenhuma ou apenas uma escola de Ensino Médio. ${ }^{71}$ Encontram-se algumas vezes separados uns dos outros por distâncias muito grandes. Mesmo dentro das cidades, costuma o transporte público estar muito aquém das necessidades de atendimento dos munícipes. Como então pensar, na prática, a implementação dos percursos formativos inseridos na LDB pela Lei 13415, mais ainda respeitando a ideia nele implícita, e muito veiculada publicitariamente, de que os jovens "vão poder escolher"? Como viabilizar, nas condições geográficas descritas, uma oferta diversificada e qualitativa de possibilidades de escolha, sobretudo levando em conta os percursos profissionalizantes, suas muitas ramificações e a necessidade de atendê-las com alguma qualidade? Sobre esse último ponto, tampouco se entende a falta de considerações sobre os caminhos de formação técnica já existentes ${ }^{72}$ e seu possível aperfeiçoamento, discutidos com alguma visibilidade, já em 2013, por Simon Schwartzman e Cláudio Moura Castro no artigo "Ensino, Formação profissional e a Questão da Mão de Obra".

Como seja, essa crucial questão tem sido tratada ora como se fosse um problema menor, ora como se já desde muito houvesse consentimento amplo à sua solução através da oferta de Educação a Distância, até porque vêm sendo empreendidos esforços para a liberalização da oferta do ensino não

70 Ver nota 64. Muito importante e impossível de abordar com o devido cuidado no escopo deste artigo é a questão do prevalecimento de interesses privados sobre os públicos na promoção dessas reformas. Em um estado democrático de direito todos os interesses têm, de fato, o direito de fazer-se representar, contanto, evidentemente, que não se produzam distorções que empurrem para a margem o interesse público. Ver a esse respeito Avellar e Ball: Mapping New Philanthropy and the Heterarchical State: the mobilization for the national learning standards in Brazil, 2016.

71 Dos 5570 municípios brasileiros, 819 (15\%) não têm nenhuma escola de Ensino Médio e 1548 (27\%) têm apenas uma. A fonte é o censo do Censo Escolar, INEP 2018.

72 Por exemplo o PRONATEC, o Sistema S e a grande oferta privada de cursos de formação técnica. Igualmente importante é não perder de vista a história da Lei 5692/1971 e sua incapacidade de fazer frente aos investimentos necessários ao seu cumprimento. 
presencial. ${ }^{73}$ Se não é, em absoluto, o caso de demonizar a modalidade a distância em si mesma, tampouco pode-se deixar de discutir as importantes especificidades desse ensino e sua aplicabilidade qualitativa, quer sob o prisma da educação integral, com seus componentes éticos, de socialização e atenção aos afetos, quer sob a ótica das demandas técnico-profissionalizantes. São muitas as variáveis a considerar, só não sendo admissível que essa modalidade apareça, tout court, como solução neutra e adequada para os problemas trazidos pela reforma em curso.

Mesmo que o avanço dessa modalidade possa ser pensado como inexorável no caudal tecnológico, não é razoável negar-lhe atenção crítica e discuti-lo com aqueles que, ao fim e ao cabo, terão que lidar com essas novas tendências. Até porque não é razoável imaginar toda uma legião de professores vencendo suas inércias didáticas em direção a um letramento digital - tampouco o seu simples descarte por "desatualização".

Seja como for, na hipótese de inviabilização política - por quaisquer caminhos - da necessária redemocratização do debate em torno do necessário enfrentamento dos nossos passivos educacionais, a estas linhas restará sobreviverem como registro, memória, fio de Ariadne ou, mais humildemente, rastro de pedrinhas deixadas pelo chão, a sinalizar o ponto onde paramos ou nos perdemos. Na crença de que os professores dos vários segmentos de ensino não podem perder-se de vista em suas recíprocas responsabilidades filosóficas, finalizo com passagem escrita sob o impacto da então recente perda da obrigatoriedade do ensino de filosofia no nível médio, para a qual não encontro boa paráfrase:

A obrigatoriedade do ensino de filosofia no nivel médio pode de fato ser questionada. Muito mais problemático seria, todavia, se com isso abríssemos mão de enfrentar os cânions do nosso momento histórico. Pois do equacionamento desse novelo de questões dependerá não apenas o mercado de trabalho dos futuros professores de filosofia, mas - sendo polissêmico, ainda que não necessariamente hiperbólico -, também o ar que respirarão nossos descendentes. A discussão sobre a maior ou menor importância do ensino de filosofia no nível médio - e sobre qual filosofia - precisa ser capaz de deflagrar outra ainda maior, aquela que se volta para nosso lugar e papel no mundo contemporâneo. ${ }^{74}$

73 Ver Governo Federal: Decreto 9057/2015.

74 Op. cit., em alteração feita na passagem original. 


\section{Referências}

ARENDT, Hannah. Entre o Passado e o Futuro. São Paulo: Ed. Perspectiva, 1997.

AVELAR, M. and BALL, Stephen. Mapping New Philanthropy and the Heterarchical State: the mobilization for the national learning standards in Brazil. International Journal of Educational Development (2017), http://dx.doi.org/10.1016/j.ijedudev.2017.09.007

ANPOF. Nota de Pesar: Falecimento do Padre Roque Zimmermann, 2019. Disponível em <http://anpof.org/portal/index.php/pt-BR/artigos-em-destaque/1987-nota-de-pesar-falecimento-do-padre-roque-zimmermann>, último acesso em 24/02/2019.

Programação do XVIII Encontro Nacional da ANPOF, 2018. Disponível em <http://anpof.org/portal/images/PROGRAMA\%C3\%87\%C3\%83O_COMPLETA8FINAL.pdf>, último acesso em 24/02/2019.

Coluna ANPOF. Disponível em <http://anpof.org/portal/index.php/pt-BR/comunidade/coluna-anpof>, último acesso em 24/02/2019.

CALlEGARI, Cesar. Carta aos Conselheiros do Conselho Nacional de Educação. Brasília, 2018. Disponível em <http://www.epsjv.fiocruz.br/carta-aos-conselheiros-do-conselho-nacional-de-educacao-cesar-callegari-renuncia-a-presidencia-da>, último acesso em 24/02/2019.

CÂMARA DOS DEPUTADOS. PL 6840/2013. Disponível em <https://www.camara. leg.br/proposicoesWeb/fichadetramitacao?idProposicao=602570>, último acesso em 24/02/2019.

PL 7180/2014. Disponível em <https://www.camara.leg.br/proposicoesWeb/fi chadetramitacao?idProposicao=606722 $>$, último acesso em 24/02/2019.

PL 246/2019. Disponível em <https://www.camara.leg.br/proposicoesWeb/fic hadetramitacao?idProposicao=2190752>, último acesso em 24/02/2019.

PL n 2/2000 e PL n 3178/1997. Disponível em <https://www.camara.leg. br/proposicoesWeb/fichadetramitacao?idProposicao=19225>, último acesso em 24/02/2019.

CAPES. Avaliação Quadrienal (2013-2016), 2017. Disponível em <http://avaliacaoquadrienal.capes.gov.br/resultado-da-avaliacao-quadrienal-2017-2>, último acesso em 24/02/2019.

OBEDUC. Disponível em <http://www.capes.gov.br/educacao-basica/observatorio-da-educacao>, último acesso em 24/02/2019.

PARFOR. Disponível em <http://www.capes.gov.br/educacao-basica/parfor>, último acesso em 24/02/2019.

PIBID, Portal. Disponível em <http://www.capes.gov.br/educacao-basica/capespibid/pibid>, último acesso em 24/02/2019.

PIBID, Portaria 38/2007. Disponível em <http://portal.mec.gov.br/arquivos/ pdf/portaria_pibid.pdf>, último acesso em 24/02/2019. 
PIBID, Portaria 46/2016. Disponível em <https://www.capes.gov.br/images/ stories/download/legislacao/15042016-Portaria-46-Regulamento-PIBID-completa. pdf>, último acesso em 24/02/2019.

PIBID, Portaria 84/2016. Disponível em <https://www.capes.gov.br/images/ stories/download/legislacao/15062016-Revogacao-da-Portaria-n-46-2016.pdf>, último acesso em 24/02/2019.

PIBID, Edital 7/2018. Disponível em <https://www.capes.gov.br/images/ stories/download/editais/01032018-Edital-7-2018-PIBID.pdf>, último acesso em 24/02/2019.

PRODOCÊNCIA. Disponível em <http://www.capes.gov.br/educacao-basica/ prodocencia>, último acesso em 24/02/2019.

Residência Docente, Edital 6/2018. Disponível em <https://www.capes.gov. br/images/stories/download/editais/01032018-Edital-6-2018-Residencia-pedagogica. pdf>, último acesso em 24/02/2019.

CEFET-RJ. Mestrado em Filosofia e Ensino. Disponível em <http://dippg.cefet-rj.br/ ppfen/index.php/pt/>, último acesso em 24/02/2019.

CNE. Resolução n. 2/2002. Disponível em <http://portal.mec.gov.br/cne/arquivos/pdf/ CP022002.pdf>, último acesso em 24/02/2019.

Resolução n4/2006. Disponível em <http://portal.mec.gov.br/setec/arquivos/ pdf/rceb04_06.pdf>, último acesso em 24/02/2019.

Resolução n. 2/2015. Disponível em <http://portal.mec.gov.br/secretaria-de-regulacao-e-supervisao-da-educacao-superior-seres/323-secretarias-112877938/ orgaos-vinculados-82187207/21028-resolucoes-do-conselho-pleno-2015>, último acesso em 24/02/2019.

Parecer 10/2017. Disponível em <http://portal.mec.gov.br/docman/agosto2017-pdf/70141-rcp001-17-pdf/file>, último acesso em 24/02/2019.

Parecer 3/2018. Disponível em <http://www.in.gov.br/materia/-/asset_publisher/Kujrw0TZC2Mb/content/id/43883704/dol-2018-10-04-resolucao-n-3-de-3-de-outubro-de-2018-43883537>, último acesso em 24/02/2019.

CEPPAS, Filipe, OLIVEIRA, Paula Ramos e SARDI, Sérgio A. (Org.). Ensino de Filosofia, formação e emancipação. Campinas: Editora Alínea, 2009.

CERLETTI, Alejandro. O ensino de filosofia como problema filosófico. Tradução de Ingrid M. Xavier. Belo Horizonte: Autêntica, 2009.

CRUZ, Márcia: EM.COM.BR, matéria de 20/08/2015. Disponível em <http://www. em.com.br/app/noticia/especiais/educacao/2015/08/20/internas_educacao,680122/ desinteresse-cresce-e-faltam-170-mil-professores-na-educacao-basica.shtml>, último acesso em 14/02/2019.

DOLTON, Peter; MERCENARO, Oscar; DE VRIES, Robert \& SHE, Po-Wen. Global Teacher Status Index 2018. Sussex: Varkey Foundation, 2108. Disponível em $<$ https://www.varkeyfoundation.org/what-we-do/policy-research/global-teacher-status-index-2018 >, último acesso em 24/02/2019. 
Brazil GTSI Statistics. Sussex: Varkey Foundation, 2108. Disponível em <2018 https://www.varkeyfoundation.org/media/4833/gtsi-brazil-chart-findings.pdf> , último acesso em 24/02/2019.

ESCOLA SEM PARTIDO. Site. Disponível em <http://www.escolasempartido.org e http://www.programaescolasempartido.org>, últimos acessos em 24/02/2019.

ESTADÃO. FHC veta filosofia e sociologia no ensino médio, publicado em 9/10/2001. Disponível em <http://politica.estadao.com.br/noticias/geral,fhc-veta-filosofia-e-Sociologia-no-ensino-medio,20011009p33663>, último acesso em 24/02/2019.

FERREIRA, Paula. Salário mínimo pago ao professor no Brasil é um dos piores do mundo, O Globo de 11/09/2018. Disponível em <https://oglobo.globo.com/sociedade/educacao/salario-minimo-pago-ao-professor-no-brasil-um-dos-piores-do-mundo-23056381>, último acesso em 24/02/2019.

FRAGA, Érica. Nenhum jovem quer virar professor no Brasil, mostra exame da OCDE, Folha de São Paulo de 7/12/2016. Disponível em <http://wwwl.folha.uol. com.br/colunas/ericafraga/2016/12/1839126-nenhum-jovem-quer-se-tornar-professor-no-brasil.shtml>, último acesso em 24/02/2019.

FREIRE, Paulo. Pedagogia do Oprimido. Rio de Janeiro: Paz e Terra, 59ª ed., 2015.

G1. Cada vez menos jovens querem ser professores no Brasil. Edição de 12/10/2016.

Disponível em <http://gl.globo.com/bom-dia-brasil/noticia/2016/10/cada-vez-menos-jovens-querem-ser-professores-no-brasil.html>, último acesso em 14/02/2019.

GALLO, Sílvio e KOHAN, Walter Omar (Org.). Filosofia no Ensino Médio. Petrópolis: Vozes, 2000.

GATTI, Bernadete, BARRETO, Elba, ANDRÉ, Marli e ALMEIDA, Patrícia: Professores do Brasil - novos cenários de formação. Brasília, UNESCO, 2019.

GHILARDI, Aline. O preconceito acadêmico contra os divulgadores. Blog Colecionadores de Ossos, 19/05/2016. Disponível em <http://scienceblogs.com.br/ colecionadores/2016/05/o-preconceito-academico-com-os-divulgadores/\#comments>, último acesso em 24/02/2019.

GONZATTO, Marcelo. Agência RBS, matéria de 13/10/2016. Disponível em <http:// www.clicrbs.com.br/especial/rs/precisamosderespostas/19,0,3916142,Por-que-apenas-2-dos-estudantes-querem-seguir-a-carreira-de-professor.html>, último acesso em 14/02/2019.

GOVERNO FEDERAL. Currículo Lattes passa por mudanças no sistema para impedir fraudes, pub. 26/07/2012, mod. 23/122017. Disponível em <http://www.brasil.gov. br/ciencia-e-tecnologia/2012/07/curriculo-lattes-passa-por-mudancas-no-sistema-para-impedir-fraudes $>$, último acesso em 24/02/2019.

. Decreto 9057/2017. Disponível em <http://www.planalto.gov.br/ccivil_03/_ Ato2015-2018/2017/Decreto/>

Lei 9394/1996 (LDB). Disponível em <http://www.planalto.gov.br/ccivil_03/ leis/L9394.htm>, último acesso em 24/02/2019.

Lei 11684/2008. Disponível em <http://www.planalto.gov.br/ccivil_03/_ ato2007-2010/2008/lei/111684.htm>, último acesso em 24/02/2019. 
. Lei 13005/2014 (PNE). Disponível em <http://www.planalto.gov.br/CCIVIL_03/_Ato2011-2014/2014/Lei/L13005.htm>, último acesso em 24/02/2019.

. Lei 13415/2017. Disponível em <http://www.planalto.gov.br/ccivil_03/_ ato2015-2018/2017/lei/L13415.htm>, último acesso em 24/02/2019.

Resolução n³ MEC/CNE/CEB, de 21/11/2018. Disponível em <http://www. in.gov.br/materia/-/asset_publisher/Kujrw0TZC2Mb/content/id/51281622>, último acesso em 24/02/2019.

GREEN, Elliot. What are the most-cited publications in the social sciences (according to Google Scholar)?, LSE Impact Blog de 12/05/2016. Disponível em <https://blogs. lse.ac.uk/impactofsocialsciences/2016/05/12/what-are-the-most-cited-publications-in-the-social-sciences-according-to-google-scholar/>, último acesso em 24/02/2019.

INEP/MEC. Censo Escolar 2018. Disponível em <http://portal.inep.gov.br/web/guest/ resultados-e-resumos>, último acesso em 24/02/2019.

INEP/MEC. PISA no Brasil, 2015. Disponível em <http://inep.gov.br/web/guest/pisa-no-brasil>, último acesso em 24/02/2019.

KELLNER, Alexandre. Divulgação científica: para quem e por quem?, in Ciência Hoje, 2013. Disponível em <http://www.cienciahoje.org.br/noticia/v/ler/id/2551/n/divulgacao_cientifica:_para_quem_e_por_quem>, último acesso em 24/02/2019.

KOHAN. Filosofia - o paradoxo de aprender e ensinar. Tradução de Ingrid Müller Xavier. Belo Horizonte: Autêntica Editora, 2009.

LYRA, Edgar; ANDRADE, Érico e NAVES DE BRITO, A.: "Entrevista com Edgar Lyra sobre a Base Nacional Comum Curricular (BNCC)". Disponível no site da ANPOF, $<$ http://anpof.org/portal/index.php/pt-BR/2014-01-07-15-22-21/entrevistas/668-entrevista-com-edgar-lyra-sobre-a-base-nacional-comum-curricular-bncc>, último acesso em 24/02/2019.

LYRA, Edgar: Sobre a Importância da Filosofia na Formação Básica, Coluna ANPOF, 2/12/2016. Disponível em <http://anpof.org/portal/index.php/en/comunidade/coluna-anpof/1008-sobre-a-importancia-da-filosofia-na-formacao-basica>, último acesso em 24/2/2019.

BNCC: para professor Edgar Lyra, formação básica não deve ter o mercado de trabalho como termo. Disponível no site da ANPOF, 2017-2018, <http://anpof.org/ portal/index.php/pt-BR/2014-01-07-15-22-21/entrevistas/1139-bncc-para-professor-edgar-lyra-formacao-basica-nao-deve-ter-o-mercado-de-trabalho-como-termo $>$, último acesso em 24/09/2019.

MEC. BNCC, 2018. Disponível em <http://basenacionalcomum.mec.gov.br/>, último acesso em 24/02/2019.

Parâmetros Curriculares Nacionais para o Ensino Médio (PCNEM), 2000.

Disponível em <http://portal.mec.gov.br/seb/arquivos/pdf/blegais.pdf>, último acesso em 24/02/2019.

Plataforma Freire, 2009. Disponível em <http://portal.mec.gov.br/component/content/article/211-noticias/218175739/13829-veja-passo-a-passo-como-usar-a-plataforma-freire>, último acesso em 24/02/2019. 
PNLD, Plano Nacional do Livro Didático, 2018. Disponível em <http://www. fnde.gov.br/pnld-2018/>, último acesso em 24/02/2019.

PRONATEC, Portal. Disponível em < http://portal.mec.gov.br/pronatec $>$, último acesso em 24/02/2019.

PROUNI - Programa Universidade para Todos. Disponível em $<$ http://prouniportal.mec.gov.br/>, último acesso em 24/02/2019.

Proposta de Base Nacional Comum de Formação de Professores da Educação Básica, 2018. Disponível em <http://portal.mec.gov.br/index.php?option=com_doc man\&view=download \&alias=105091-bnc-formacao-de-professores-v0\&category_ slug=dezembro-2018-pdf\&Itemid=30192>, último acesso em 24/02/2019.

Portaria 1432/2018. Disponível em http://www.in.gov.br/materia/-/asset_publisher/Kujrw0TZC2Mb/content/id/70268199, último acesso em 24/02/2019.

OECD. Education at a Glance 2018: OECD Indicators. Paris: OECD Publishing, 2018. <http://dx.doi.org/10.1787/eag-2018-en. Disponível também em http://download.inep.gov.br/acoes_internacionais/eag/documentos/2018/EAG_Relatorio_na_integra.pdf>, último acesso em 24/02/2019.

PORTA, Mario A. González. A Filosofia a partir dos seus problemas. São Paulo: Loyola, 2002.

PUC-Rio. Fundo Emergencial de Solidariedade da PUC-Rio. Disponível em http:// www.puc-rio.br/vrc/respuc/membros/fesp.html , último acesso em 24/02/2019.

Manual do Candidato 2019. Disponível em <http://www.puc-rio.br/vestibular/201812/pdf/manual201812.pdf>, último acesso em 24/02/2019.

REEDY, Christianna: Kurzweil Claims That the Singularity Will Happen by 2045, in Futurism, 5/10/2017. Disponível em https://futurism.com/kurzweil-claims-that-the-singularity-will-happen-by-2045, último acesso em24/02/2019.

ROCHA, Ronai Pires. Ensino de Filosofia e Currículo. Petrópolis: Vozes, 2008. to, 2017 ,

Quando Ninguém Educa - questionando Paulo Freire. São Paulo: Editora Contex-

SCHWARTZMAN, Simon e MOURA CASTRO, Cláudio. Ensino, Formação profissional e a Questão da Mão de Obra. Ensaio: Avaliação de Políticas Públicas de Educação, v.21, n.80, p.663-624,jul.-set. 2013.

UFPR: PROF-FILO. Disponível em <http://www.humanas.ufpr.br/portal/prof-filo/ , último acesso em 24/02/2019>

VEIGA, Edson. Paulo Freire - como o legado do educador brasileiro é visto no exterior, in BBC News Brasil, 2/1/2019. Disponível em <https://www.bbc.com/portuguese/ brasil-46830942>, último acesso em 24/02/2019.

VICHESSI, Beatriz e SILVA, D. Araujo. Revista Nova Escola, Edição 312, 03 de Maio de 2018. Disponível em <https://novaescola.org.br/conteudo/11707/maranhao-enfrenta-o-desastre-educacional> último acesso em 24/02/2019. 


\section{Referências em vídeo}

LYRA, Edgar. BNCC 1: A participação de professores e professoras no debate. In ANPOF, Canal Oficial no Youtube, publicado em 13/08/2018. Disponível em <https:// www.youtube.com/watch?v=vSNsQFF17vk>, último acesso em 24/02/2019.

BNCC 2: Algumas associações pedem a sua revogação. Revogar ou adaptar? Qual a melhor saída? In ANPOF, Canal Oficial no Youtube, publicado em 14/08/2018. Disponível em <https://www.youtube.com/watch?v=TyBx5HzzCSc>, último acesso em 24/02/2019.

BNCC 3: Prejuízos. In ANPOF, Canal Oficial no Youtube, publicado em 16/08/2018. Disponível em <https://www.youtube.com/watch?v=TZ4jY5RvJ9w >, último acesso em 24/02/2019.

BNCC 4: Como afeta nossa área? In ANPOF, Canal Oficial no Youtube, publicado em 17/08/2018. Disponível em <https://www.youtube.com/ watch?v=7XbA7VpJOy4 >, último acesso em 24/02/2019.

BNCC 5: O que pode mudar a longo prazo? In ANPOF, Canal Oficial no Youtube, publicado em 20/08/2018. Disponível em <https://www.youtube.com/ watch?v=7e_D2JSN9qM>, último acesso em 24/02/2019. 